\title{
A Study on Geopolymer with Dyeing Industry Effluent Treatment Plant Sludge
}

\author{
Raghunathan T \\ Lecturer/Civil, Department of Civil Engineering, \\ P.A.C. Ramasamy Raja Polytechnic College, Rajapalayam, Tamil Nadu, India
}

\begin{abstract}
In this paper, it is envisaged to project a new composite material, which can be made from the existing non-degradable and hazardous waste materials. The composite material is a combination of Fly ash Geopolymer (FAG) and Dyeing Industry Effluent Treatment plant Sludge (DIETP-S). The composite thus obtained is christened as GeopolymerDye Sludge Composite (GDSC). It is the method of extracting wealth from the waste. In this research Sodium hydroxide $(\mathrm{NaOH})$ solution of mole 10 was used as alkali activator for fly ash to manufacture FAG. Silica gel (SG) was added to one set of GDSC samples. The DIETP-S was used as inert filler in the FAG in various percentages. Curing was done at 800 $\mathrm{C}$ for 1 day. The compressive strength and leaching of chemicals into water as Total Dissolved solids (TDS) are studied. It is envisaged that this GDSC reduces the environmental hazards caused by fly ash from thermal power plants and sludge from dyeing industries.
\end{abstract}

Key Words: Composite, Geopolymer, Fly ash, Dyeing Industry Effluent Treatment Plant Sludge, Fly ash Geopolymer \& Geopolymer-Dye Sludge composite

\section{INTRODUCTION}

Geopolymer was first mentioned by Davidovits in the early 1970 s, to describe inorganic materials with polymeric Si-O-Al bonds obtained from the chemical reaction of alumino -silicate oxides with alkali silicates $^{3}$. According to Davidovits ${ }^{2}$, the empirical formula of geopolymers or poly-sialates is as follows:

$$
\mathrm{M}_{\mathrm{n}}\left\{-\left(\mathrm{SiO}_{2}\right)_{\mathrm{z}}-\mathrm{AlO}_{2}\right\}_{\mathrm{n}}-\mathrm{wH}_{2} \mathrm{O}
$$

Where $\mathrm{M}$ is a cation such as $\mathrm{K}+, \mathrm{Na}+$ or $\mathrm{Ca} 2+, \mathrm{n}$, the degree of polycondensation and $\mathrm{z}$ is 1,2 or 3 . Other cations such as $\mathrm{Li}+, \mathrm{Ba}^{2+}, \mathrm{NH}^{4+}$ and $\mathrm{H}_{3} \mathrm{O}^{+}$may also be present.
The synthesis of Geopolymer binders is successful alternative, giving rise to low cost and environmentally friendly materials with cementing properties resembling those of $\mathrm{OPC}^{2}$.

Fly ash (FA) is a waste product from thermal power plants and cement plants. The worldwide production of fly ash is achieving 800 million tonnes per year in $2010^{6}$. The fly ash used in my research has un compacted density of $229 \mathrm{~kg} / \mathrm{m}^{3}$, specific gravity of 1.58 \& fineness modulus of 2.69 .

DIETP-S is classified as hazardous waste ${ }^{9}$, generated during the treatment of textile effluents. Tonnes of sludge generated in and piled up at common and individual effluent treatment plants.8.8-crore litres of effluents, after primary treatment in effluent treatment plants, are being let out into the Noyyal River every day in Thiruppur alone ${ }^{8}$. One tonne of dewatered sludge is produced for every $500-1000 \mathrm{~m}^{3}$ of effluent treated ${ }^{4}$. They all generate sludge to an estimate'd 88 tonnes a day in Thiruppur alone. The sludge, a highly hazardous waste, is stored in open yards. The industry also struggles to find a place for a landfill of this sludge. "Landfill is not a solution to pollution" as during rains the DIETP-S dissolves in rain water and leaches in to the ground and runoff from these yards pollutes rivers. DIETP-S used in the research contains chlorides of $0.51 \%$, sulphate of $5.71 \%$ and calcium $(\mathrm{CaO})$ of $30.76 \%$ by weight.

In this paper it is envisaged to create a new composite GDSC using FAG and DIETP-S with SG and without SG keeping the ratio of silica gel as $12.5 \%$ by weight of fly ash. DIETP-S is added to FAG as inert filler in various percentages, viz. $5 \%, 10 \%, 15 \%$ and $20 \%$. 


\section{REVIEW OF LITERATURE}

Ramesh Kumar ${ }^{7}$, et al, has done extensive study on dye effluents in Perundurai. He says that, Textile dyeing industries in Erode and Tirupur district of Tamilnadu (India) discharge effluents ranging between 100 and $200 \mathrm{~m}^{3} / \mathrm{t}$.

Hilary $\mathrm{Nath}^{4}$ has produced bricks from the primary sludge generated in the garment washing process. The sludge brick was tested for the common parameter for a building block.

Balasubramanian ${ }^{1}$, et al, has studied the potential reuse of textile effluent treatment plant (ETP) sludge in building materials.

Yamaguchi Norio ${ }^{10}$, et al carried out Solidification of SSS (sewage sludge slag) by the geopolymer binder technique at $80^{\circ} \mathrm{C}$ steam conditions mixed with $\mathrm{CFA}$ (coal fly ash).

Zheng $^{11}$, et al. say that geopolymer has a very low rate of green house gas emission when compared to ordinary Portland cement.

\section{RESEARCH METHODOLOGY}

AG was manufactured by mixing FA collected from thermal power plant, Tuticorin, with 10 mole $\mathrm{NaOH}$ as alkali activator in 3:1 ratio. That is 3 parts $\mathrm{FA}$ and 1 part $\mathrm{NaOH}$.

The DIETP-S was collected from a dyeing industry near Thiruppur. The chemical composition of DIETP$\mathrm{S}$ was found. The DIETP-S was mixed with FAG as inert filler in various percentages by weight of FA, viz. $5 \%, 10 \%, 15 \%$ and $20 \%$ to create a GDSC. The GDSC was manufactured without SG as first set of samples.

SG was added to GDSC keeping the SG weight as $12.5 \%$ of weight of FA for second set of samples.

The GDSC was cast in $70.71 \mathrm{~mm}$ cement mortar cube moulds. The GDSC cubes were put in the oven at $80 \mathrm{oC}$ for 24 hours. Then they were kept at room temperature for 13 days.

After 14 days tests were conducted on the GDSC cubes. Compressive strength of GDSC without SG and GDSC with SG was compared.

Leaching of chemicals in water as the Total Dissolved Solids (TDS) in water in parts per million (PPM) was compared for GDSC without SG and GDSC with SG.
For comparing the leaching of GDSC with Cement, a cement mortar $(\mathrm{CM})$ cube of mix 1:3 was cast with water cement ratio as 0.85 percentage of consistency $33 \%$.

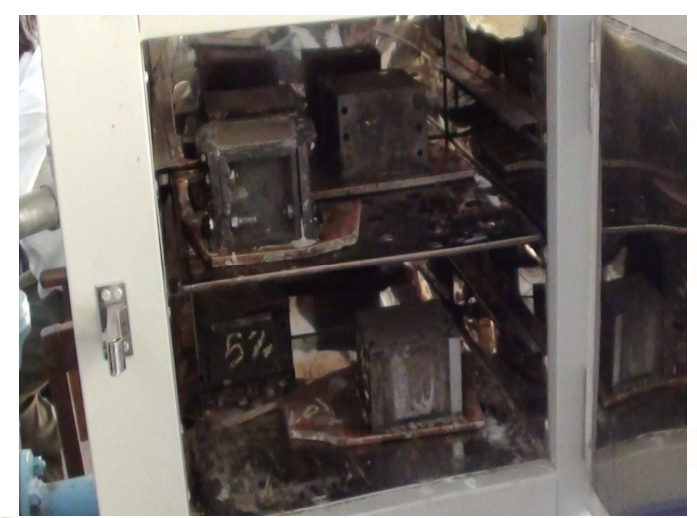

Figure 1: Photo of GDSC in oven at $80 \mathrm{oC}$

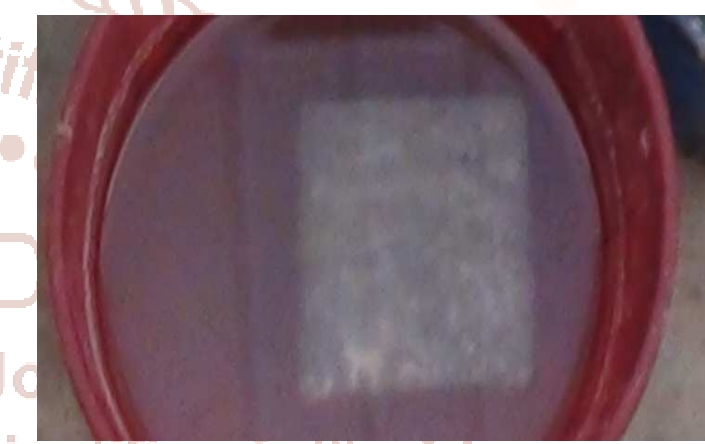

Figure 2: Photo of GDSC tested for Leaching

IV. ANANALYSIS AND INTERPRETATION

TABLE 1: Compressive strength of GDSC

\begin{tabular}{|c|c|c|}
\hline \multirow{2}{*}{ Mix } & \multicolumn{2}{|c|}{$\begin{array}{c}\text { Compressive strength of } \\
\text { GDSC cubes in N/mm }\end{array}$} \\
\cline { 2 - 3 } & GDSC & GDSC + SG \\
\hline Plain (pl) & 8.09 & 12.22 \\
\hline $5 \%$ & 7.25 & 10.98 \\
\hline $10 \%$ & 7.14 & 9.37 \\
\hline $15 \%$ & 6.05 & 9.48 \\
\hline $20 \%$ & 5.73 & 7.78 \\
\hline
\end{tabular}

Where "plain" is GDSC without DIETP-S, 5\% is GDSC with 5\% DIETP-S, $10 \%$ is GDSC with10\% DIETP-S so on...

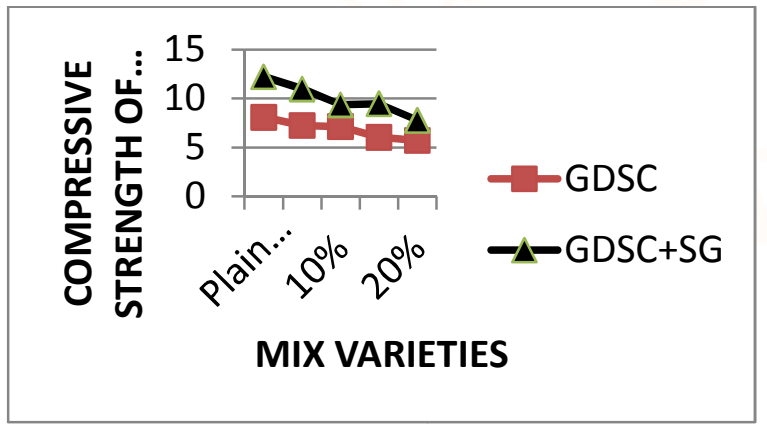

Figure 3: Chart of compressive strength of GDSC mixes 
International Journal of Trend in Scientific Research and Development (IJTSRD) ISSN: 2456-6470

TABLE 2: leaching of salts into water

Measured as tds in ppm for plain gdsc

\begin{tabular}{|c|c|c|c|}
\hline \multirow{2}{*}{ Days } & \multicolumn{3}{|c|}{$\begin{array}{c}\text { Leaching of salts into water } \\
\text { measured as TDS in PPM }\end{array}$} \\
\cline { 2 - 4 } & GDSC & GDSC + SG & Cement Mortar \\
\hline 0 & 79 & 120 & 124 \\
\hline 1 & 200 & 218 & 313 \\
\hline 2 & 208 & 280 & 385 \\
\hline 3 & 238 & 328 & 432 \\
\hline 4 & 274 & 376 & 479 \\
\hline
\end{tabular}

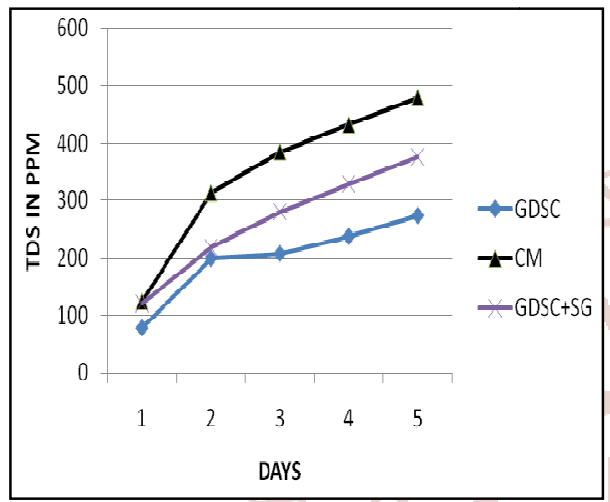

Figure 4: Chart of Leaching of salts into water measured as TDS in PPM for GDSC 5\%

TABLE 3: Leaching of salts into water measured as TDS in PPM for GDSC 5\%

\begin{tabular}{|c|c|c|c|}
\hline \multirow[b]{2}{*}{ Days } & \multicolumn{3}{|c|}{$\begin{array}{l}\text { Leaching of salts into water } \\
\text { measured as TDS in PPM }\end{array}$} \\
\hline & $\begin{array}{l}\text { GDSC with } \\
5 \% D I E T P-S\end{array}$ & $\begin{array}{l}\text { GDSC with } \\
5 \% \text { DIETP- } \\
\text { S + silica gel }\end{array}$ & $\begin{array}{l}\text { Cement } \\
\text { Mortar }\end{array}$ \\
\hline 0 & 124 & 133 & 124 \\
\hline 1 & 330 & 304 & 313 \\
\hline 2 & 390 & 334 & 385 \\
\hline 3 & 441 & 370 & 432 \\
\hline 4 & 480 & 402 & 479 \\
\hline
\end{tabular}

Note: In figure 5\% +SG is GDSC with $5 \%$ DIETP-S + silica gel.

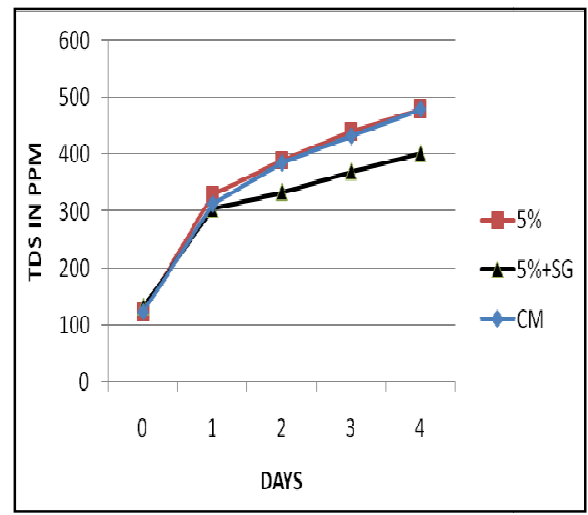

Figure 5: Chart of Leaching of salts into water measured as TDS in PPM for GDSC 5\%
TABLE 4: Leaching of salts into water

Measured as TDS in PPM for GDSC 10\%

\begin{tabular}{|c|c|c|c|}
\hline \multirow{4}{*}{ Days } & \multicolumn{3}{|c|}{$\begin{array}{c}\text { Leaching of salts into water } \\
\text { measured as TDS in PPM }\end{array}$} \\
\cline { 2 - 4 } & $\begin{array}{c}\text { GDSC with } \\
10 \% \text { DIETP-S }\end{array}$ & $\begin{array}{c}\text { GDSC with } \\
10 \% \text { DIETP-S } \\
+ \text { SG }\end{array}$ & $\begin{array}{c}\text { Cement } \\
\text { Mortar }\end{array}$ \\
\hline 0 & 124 & 137 & 124 \\
\hline 1 & 390 & 288 & 313 \\
\hline 2 & 464 & 350 & 385 \\
\hline 3 & 495 & 393 & 432 \\
\hline 4 & 522 & 416 & 479 \\
\hline
\end{tabular}

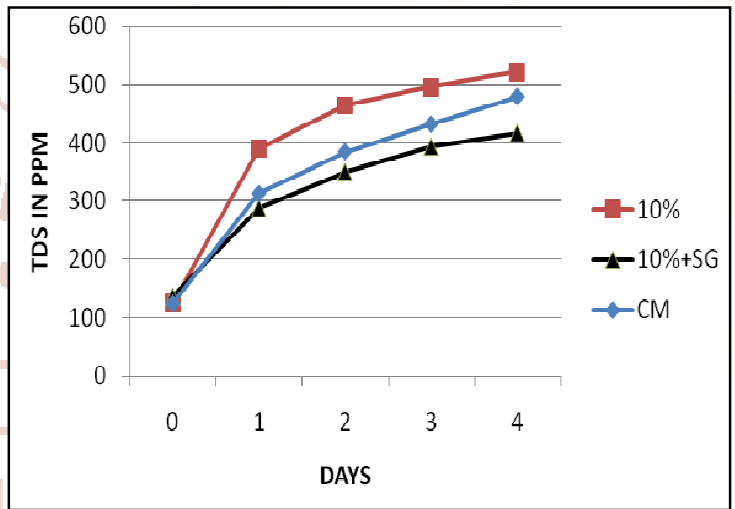

Figure 6: Chart of Leaching of salts into water measured as TDS in PPM for GDSC $10 \%$

TABLE 5: Leaching of salts into water Measured as TDS in PPM for GDSC $15 \%$

\begin{tabular}{|c|c|c|c|}
\hline \multirow{4}{*}{ Days } & \multicolumn{3}{|c|}{$\begin{array}{c}\text { Leaching of salts into water } \\
\text { measured as TDS in PPM }\end{array}$} \\
\cline { 2 - 4 } & $\begin{array}{c}\text { GDSC with } \\
\text { 15\% DIETP-S }\end{array}$ & $\begin{array}{c}\text { GDSC with } \\
\text { 15\% DIETP-S } \\
+ \text { SG }\end{array}$ & $\begin{array}{c}\text { Cerment } \\
\text { Mortar }\end{array}$ \\
\hline 0 & 124 & 131 & 124 \\
\hline 1 & 313 & 260 & 313 \\
\hline 2 & 384 & 300 & 385 \\
\hline 3 & 432 & 348 & 432 \\
\hline 4 & 452 & 396 & 479 \\
\hline
\end{tabular}

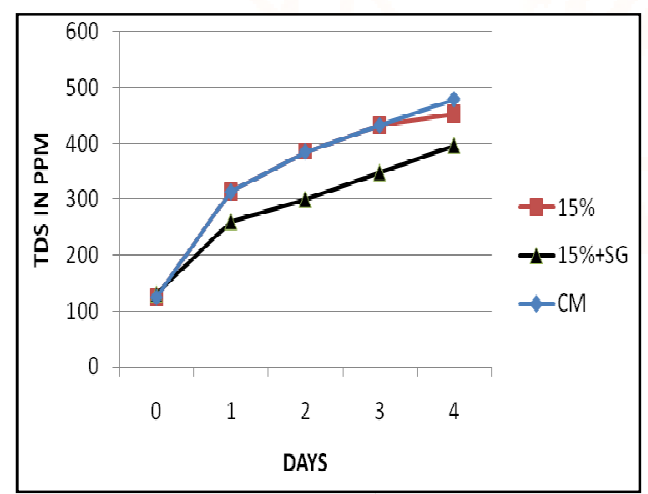

Figure 7: Chart of Leaching of salts into water measured as TDS in PPM for GDSC $10 \%$ 
International Journal of Trend in Scientific Research and Development (IJTSRD) ISSN: 2456-6470

Table 6: Leaching of salts into water measured as TDS in PPM for GDSC 20\%

\begin{tabular}{|c|c|c|c|}
\hline \multirow{4}{*}{ Days } & \multicolumn{3}{|c|}{$\begin{array}{c}\text { Leaching of Salts Into Water } \\
\text { Measured As TDS In PPM }\end{array}$} \\
\cline { 2 - 4 } & $\begin{array}{c}\text { GDSC With } \\
20 \% \text { DIETP-S }\end{array}$ & $\begin{array}{c}\text { GDSC With } \\
\text { 20\% DIETP-S } \\
\text { + Silica Gel }\end{array}$ & $\begin{array}{c}\text { Cement } \\
\text { Mortar }\end{array}$ \\
\hline 0 & 124 & 136 & 124 \\
\hline 1 & 385 & 259 & 313 \\
\hline 2 & 457 & 313 & 385 \\
\hline 3 & 494 & 352 & 432 \\
\hline 4 & 546 & 391 & 479 \\
\hline
\end{tabular}

GDSC as compared to the leaching of salts from CM cube and GDSC without SG cubes.

\section{REFERENCES}

1. Balasubramaniana J., et. al., (2005), "Reuse of textile effluent treatment plant sludge in building materials", Elsevier Ltd , online paper, 11 January 2005, pp. 1.

2. Dadidovits. J, J. Therm Anal.,(1991), 37, p.1633

3. Dadidovits. J, (1979) SPEPACTEC '79, Society of plastic Engineers, , USA, p.151

4. Hilary Nath (2006), "Sludge-Bricks Development", Reach, Brandix inspired solutions, Issue 3, pp. 6.

5. IS-3495 (part - I)-1976 -“Determination of compressive strength, Methods of test of burnt clay bricks"

6. Palomo A. et. al. (2005) Cement Concrete Research, 35,P.1984.

7. Ramesh Kumar M., et al,, (2008), "Recycling of Woven Fabric Dyeing Wastewater Practiced in Perundurai Common Effluent Treatment Plant". SSM College of Engineering.

Figure 8: Chart of Leaching of salts in water measured as TDS in PPM for GDSC 10\%

\section{CONCLUSIONS}

$>$ An environment friendly and innovative composite, GDSC is obtained in this research.

$>$ Both GDSC with SG and GDSC without SG show appreciable reduction of compressive strength with increase in DIETP-S.

$>$ Strength of GDSC with SG is 2 to $4 \mathrm{~N} / \mathrm{mm} 2$ greater than GDSC without SG.

$>$ But we can manufacture bricks with compressive strength of second class bricks as per IS-3495 (part - I)-19765 using GDSC with 10\% DIETP-S with SG or without SG.

$>$ Thereby we can create wealth by combining the two wastes viz. FA and DIETP-S.

$>$ From the leaching results, it is evident that the leaching of salts decreases with addition of SG in

8. Ranganathan K., et. al. "Recycling of wastewaters of textile dyeing industries using advanced treatment technology and cost analysis"-Case studies. Central Pollution Control Board, Southern Zonal Office, Rajajinagar, Bangalore 560 086, India.

9. Renganathan L (2009), "Safe disposal of sludge, a problem", Online edition of India's National Newspaper, The Hindu.

10. Yamaguchi Norio and Ko Ikeda (2010), Journal of the Ceramic Society of Japan, Vol. 118 (2010), No. 1374 (February) pp.107-112

11. Zheng Xun Yang, et. al, (2009), Journal of Ceramic Processing Research. Vol. 10, No. 3, pp. 266 268 